\title{
"Quebracho" tannin derivative and boosters biocides for new antifouling formulations
}

\author{
N. Bellotti, C. Deyá, B. del Amo, R. Romagnoli
}

(C) ACA and OCCA 2012

\begin{abstract}
The growth of fouling communities on ships' hulls causes economic losses due to increased fuel consumption and to the deterioration of the metallic substrate by corrosion. Antifouling paints are formulated to avoid the settlement of these organisms and may contain biocides as active compounds. The objective of this research was to evaluate the antifouling performance of paints formulated with a "quebracho" tannin derivative (zinc "tannate") and "boosters" (secondary biocides). The "boosters" used in this study were bismuth lactate, a zeolite exchanged with silver cations, and the same zeolite modified with silver chloride. Bioassays with "boosters" solutions were carried out employing Artemia persimilis. Soluble matrix antifouling paints were formulated and their action was assessed in a natural sea water environment. Results showed that the bismuth lactate resulted in a coating with almost triple service life of the antifouling paints with zinc "tannate." Paints formulated with the silver composites behaved slightly better than the control paint.
\end{abstract}

Keywords Coatings, Tannin, Biocides, Antifouling paints, Composite materials

\section{Introduction}

From ancient times, different types of coatings have been used to prevent the settlement of marine organisms on ships' hulls. The growth of the biofouling community on ships' hulls causes economic losses due to the increased fuel consumption required to keep the cruising speed.

N. Bellotti ( $\bowtie)$, C. Deyá, B. del Amo,

R. Romagnoli

CIDEPINT - Centro de Investigación y Desarrollo en Tecnología de Pinturas (CIC-CONICET), Calle 52 e/121 y 122, B1900AYB La Plata, Argentina

e-mail: estelectro@cidepint.gov.ar; nataliabe9@hotmail.com
They may also deteriorate the metallic substrate by corrosion. Antifouling paints are formulated to avoid the settlement of these fouling organisms, and most of them contain biocides in their formulation. Copper and copper oxides are commonly employed as biocides, but their use is being restricted because recent reports have shown high levels of copper in marine waters. ${ }^{1}$ Apart from copper, other metals with antifungal and antibacterial properties, such as zinc and silver, have been widely used in advanced coating technology. ${ }^{2}$

More recently, natural products are being employed as possible replacements for conventional metallic biocides. ${ }^{3}$ In this context, it was demonstrated that tannins possess a narcotic effect on Balanus amphitrite (barnacle) nauplii; therefore, they became materials of interest in the field of antifouling coatings. ${ }^{4}$ Tannins are polyphenols produced naturally by different plants which use the former as a defense against bacteria, fungi, etc. ${ }^{5,6}$ Their influential action rests upon three different but complementary mechanisms: (a) the ability of tannin to subtract metallic ions involved in microorganisms' vital processes, (b) the inhibition of the enzymatic activity, and (c) the influence on the oxidative phosphorylation at the membrane level. ${ }^{7}$ Tannin extracts are not used directly in paints because they are highly soluble in water. However, the employment of less-soluble compounds, obtained by coagulation with metallic cations, such as aluminum, copper, and zinc, was reported in the literature. ${ }^{4}$ Aluminum tannate was found to last for 1 month after being incorporated into a gel, while a paint formulated with copper "tannate" presented no macrofouling after 12 months. ${ }^{4,8}$ The antifouling efficiency diminished when copper was substituted by zinc in the corresponding "tannate", 9 but service life could be extended if suitable boosters are selected.

"Boosters," or secondary biocides, enhance antifoulants' action, the concentration of which in the paint film may be reduced. The impact of these "boosters" 
on the environment is still a matter of discussion because some of them are chloride derivatives of organic compounds. ${ }^{10,11}$ Compounds with recognized antibacterial or antifungal activities which have been used previously in the industry, in medical therapy, etc., are also candidate substances to be employed as secondary antifoulants. ${ }^{2,12-14}$

The antifouling efficiency of a paint containing zinc "tannate," WW rosin (water white variety commonly used in antifouling paints), and styrene acrylate copolymer (SAC) as the binders proved effective for a period up to 3 months in natural sea water (NSW). ${ }^{9}$ The aim of the present investigation was to extend the service life of this paint by incorporating new secondary biocides or "boosters" having less environmental impact than those commonly employed. ${ }^{12,15}$ Three "boosters"- bismuth lactate, silver-exchanged zeolite, and silver chloride supported on zeolites-were selected because of their antimicrobial characteristics. These compounds had previously been employed in the food industry and medical applications. ${ }^{16-21}$

\section{Materials and methods}

\section{Pigment and "boosters" preparation and characterization}

The antifouling pigment was obtained from "Quebracho colorado" (Schinopsis balansae) tannin. "Quebracho colorado" is a characteristic argentine tree which contains high amounts of polyphenols, easily extractable by hot water. In order to obtain the corresponding "tannate," the tannin was dispersed in distilled water, and $0.65 \mathrm{M}$ zinc nitrate was added to the suspension with continuous stirring. The $\mathrm{pH}$ was adjusted to 4 with the addition of $0.5 \mathrm{M}$ sodium hydroxide after the addition of zinc nitrate, the $\mathrm{pH}$ being controlled periodically. ${ }^{9}$ The zinc "tannate" (TZn4) was separated from the supernatant by filtration, washed three times with distilled water, centrifuged, and dried at room temperature under an air current and, finally, in an oven at $50 \pm 5^{\circ} \mathrm{C}$.

The amount of tannin in TZn 4 was obtained by indirect gravimetry, heating the solid at $100 \pm 5^{\circ} \mathrm{C}$ to eliminate water. On further heating to $800-900^{\circ} \mathrm{C}$, zinc was converted to zinc oxide and weighed to estimate the zinc content in TZn4. The density of the pigment, needed for paint formulation, was determined according to a standard specification (ASTM D 1475).

The solubility of TZn4 in artificial sea water (ASW) was obtained by dispersing $2 \mathrm{~g}$ of the pigment in $100 \mathrm{~mL}$ of ASW at $20 \pm 2^{\circ} \mathrm{C}$ for $24 \mathrm{~h}$. The ASW was prepared according to ASTM D 1141. The solid was separated by filtration; both tannin, as total polyphenols (TP), and zinc were determined in the filtrate. The concentration of tannin was obtained spectrophotometrically at $750 \mathrm{~nm}$ using the Folin-Denis reagent (FDr). ${ }^{22-24}$ Zinc was determined by atomic absorption spectroscopy.

Bismuth lactate and bismuth oxichloride were reagent grade chemicals purchased from Merck. The amount of bismuth in the saturated solution was determined spectrophotometrically at $465 \mathrm{~nm}$ complexing it with thiourea in nitric acid medium. ${ }^{25}$ The concentration of lactate in the saturated solution was determined by UV-Vis spectrophotometer at $215 \mathrm{~nm}$, employing sodium lactate solutions to build up the calibrations curve.

The X-ray diffraction pattern of the zeolitic rock was recorded employing a PAN analytic X'Pert PRO equipment with $\mathrm{Cu}$ anodes and a graphite monochromator. The exchanged zeolites were prepared as follows: $50 \mathrm{~g}$ of the zeolitic rock was ground and washed twice with distilled water and boiled for $1 \mathrm{~h}$ in $\mathrm{HNO}_{3} 0.2 \mathrm{M}$ to eliminate iron. The complete elimination of iron was accomplished by means of a magnetic stirrer. Then, the zeolite powder was washed again with distilled water and exchanged for $24 \mathrm{~h}$ with $\mathrm{NaNO}_{3} 2 \mathrm{M}$ to put the zeolite in the $\mathrm{Na}^{+}$form. Finally, the sodiumexchanged zeolite was brought into contact with $1 \mathrm{M}$ $\mathrm{AgNO}_{3}$ for 1 day to exchange $\mathrm{Na}^{+}$with $\mathrm{Ag}^{+}$(ZAg). The exchanged zeolite was separated by centrifugation, washed twice with distilled water, and dried at $50 \pm 5^{\circ} \mathrm{C}$ in a stove. The $\mathrm{ZAg}$ was dispersed in $0.1 \mathrm{M}$ $\mathrm{NaCl}$, previous to centrifugation, to obtain the zeolite modified with $\mathrm{AgCl}$ (ZAgCl). Afterwards, it was centrifuged and washed twice with distilled water. ${ }^{26}$

The amount of silver exchanged by ZAg was determined by titration with KSCN, employing the Volhard's method. ${ }^{27}$ Previously, ZAg was back exchanged with $10 \% \mathrm{NaCH}_{3} \mathrm{COOH}$ for $2 \mathrm{~h}$ to replace all the silver ions with sodium. After being in contact for $24 \mathrm{~h}$, the supernatant was separated by vacuum filtration, and the solid precipitate was washed five times with distilled water. The supernatant and the washing solutions were placed in a volumetric flask, and $50 \mathrm{~mL}$ of this solution were titrated with KSCN $0.0488 \mathrm{~N}$ employing a $1.25 \mathrm{M}$ $\mathrm{Fe}\left(\mathrm{NO}_{3}\right)_{3}$ nitric solution as indicator.

A given amount of $\mathrm{ZAgCl}$ was brought into contact with a $\mathrm{NH}_{4} \mathrm{NO}_{3} / \mathrm{NH}_{3} 2 \mathrm{M} / 2 \mathrm{M}$ solution and stirred for $2 \mathrm{~h}$, just to dissolve silver chloride by complexation. After $24 \mathrm{~h}$, the supernatant was separated as before, washed five times, and then placed in a volumetric flask. $\mathrm{As} \mathrm{AgCl}$ precipitates in acidic medium, the titration was done with a $0.0184 \mathrm{M} \mathrm{KCN}$ solution according to Liebig's method with the modification introduced by Denigès to detect the end point. ${ }^{28}$ The excess of $\mathrm{CN}^{-}$was titrated with $\mathrm{AgNO}_{3} 0.05 \mathrm{~N}$ solution employing $1 \mathrm{~mL}$ of $10 \%$ IK as indicator.

All the determinations were done in duplicate employing two different samples in the case of the exchanged zeolites.

\section{Bioassays}

The biocidal action of the different compounds and "composites" employed in this research was assessed by screening bioassay to provide adequate information for the development of antifouling coatings. ${ }^{29}$ Artemia (brine shrimp) larvae are used extensively as test 
organisms in research studies and applied toxicology because of the commercial availability of dried cysts from which live material can be hatched easily. ${ }^{30,31}$ Toxicity tests with Artemia nauplii are quick and inexpensive; they are also found to possess good predictive potential. These biological assays constitute an alternative to others with crustacean larvae, principally those from barnacles (B. amphitrite, for example). ${ }^{32,33}$

The "booster" concentration which kills $50 \%$ of the Artemia nauplii within $24 \mathrm{~h}\left(\mathrm{LC}_{50}\right)$ was determined experimentally using a short-term toxicity test. ${ }^{30}$ Artemia persimilis eggs commercially obtained were hatched in ASW (ASTM D1141-98) at $24 \pm 2{ }^{\circ} \mathrm{C}$ for $24 \mathrm{~h}$ under gentle aeration with an aquarium pump. ${ }^{30}$ Finally, after $48 \mathrm{~h}$, a homogenous population of instar II-III nauplii was obtained and used for the bioassays.

Zinc tannate and Boosters-saturated solutions in ASW were prepared at $25^{\circ} \mathrm{C}$ for further dilutions to determine $\mathrm{LC}_{50}$.

Several dilutions of the zinc tannate-saturated solution in ASW were prepared in such a way that they finally contained $10,50,100,120$, and $200 \mathrm{mg} / \mathrm{L}$ of TP. The corresponding zinc cation concentrations were 0.1 , $0.4,1.0$, and $1.6 \mathrm{mg} / \mathrm{L}$, respectively.

From the saturated solution of bismuth lactate in ASW, adequate dilutions were made to obtain different concentrations of lactate in ASW: 950, 930, 900, 750, 400 , and $200 \mathrm{mg} / \mathrm{L}$. The corresponding $\mathrm{Bi}(\mathrm{III})$ concentrations were: $0.10,0.09,0.08,0.04,0.02$, and $0.01 \mathrm{mg} / \mathrm{L}$, respectively. In addition, lactate and bismuth ions were tested separately to determine the bioactivity of each species. A sodium lactate solution in ASW was prepared by neutralizing a $10,000 \mathrm{mg} / \mathrm{L}$ lactic acid solution with $1 \mathrm{M} \mathrm{NaOH}$. This solution was diluted with ASW to obtain different concentrations of sodium lactate: $2500,1000,500,250,100$, and $50 \mathrm{mg} / \mathrm{L}$. The final $\mathrm{pH}$ value obtained for these solutions was between 7 and 8. On the other hand, an oxichloride bismuth saturated solution in ASW was prepared as a source of $\mathrm{Bi}$ (III) to determine LC50. Aliquots of 50, 25, 12.5, and $6.25 \mathrm{~mL}$ were each diluted to $100 \mathrm{~mL}$ with ASW.

The saturated solutions obtained by dispersing ZAg or $\mathrm{ZAgCl}$ in ASW were diluted as follows: $25,12.5$, and $6.25 \mathrm{~mL}$ up to $100 \mathrm{~mL}$ of ASW. The saturated solutions were also tested to determine $\mathrm{LC}_{50}$.

The biological assays to determine $\mathrm{LC}_{50}$ for the different "boosters" were carried out by placing 10 nauplii in different vessels with $10 \mathrm{~mL}$ of the corresponding solution. A vessel with ASW was used as control. Three replicates were set up for each concentration and for the control. After an incubation period of $24 \mathrm{~h}$, dead larvae were counted and $\mathrm{LC}_{50}$ values were calculated by Probit analysis. ${ }^{34}$

\section{Formulation, preparation, and application of the antifouling paints}

The paints were prepared employing WW rosin, provided by Cicloquímica, as film-forming material.
Table 1: Paint composition expressed as percentage of solids by volume and by weight

\begin{tabular}{lcc} 
Components & $\begin{array}{c}\text { Composition } \\
\text { (vol\%) }\end{array}$ & $\begin{array}{c}\text { Composition } \\
\text { (wt\%) }\end{array}$ \\
\hline TZn4 & 34.1 & 36.5 \\
Chalk & 8.7 & 17.6 \\
WW rosin & 32.3 & 26.1 \\
Styrene acrylate copolymer & 16.9 & 13.0 \\
Plasticizer & 6.6 & 5.8 \\
Pine oil & 0.5 & 0.3 \\
Castor oil & 0.9 & 0.7 \\
\hline
\end{tabular}

Table 2: Boosters incorporated into the paints

\begin{tabular}{llccc} 
Paints & A & B & C & D \\
\hline $\begin{array}{c}\text { Secondary } \\
\text { biocide (booster) }\end{array}$ & - & Bismuth lactate & ZAg & ZAgCl \\
\hline
\end{tabular}

The SAC, purchased from Arquimex, was added as cobinder, with the ratio of WW rosin/SAC being 1.9/1, by volume. The plasticizer was chlorinated paraffin with $42 \%$ of chloride (Cereclor 42 ); the ratio SAC/plasticizer was $2.6 / 1$, by volume.

Rosin was dissolved in xylene employing a high speed disperser, while SAC was dispersed in xylene together with the plasticizer. The pigments (chalk and TZn4) were dispersed in a fraction of the solvent in a ball mill jar. Then, both vehicles and pine oil were incorporated into the jar with the pigments and dispersed for $24 \mathrm{~h}$. Finally, castor oil gel was added. ${ }^{9}$ Paint composition can be seen in Table 1. Pine and castor oil were obtained from a local supplier, Cicloquímica.

From the base formulation reported in Table 1, four paints were prepared by adding different boosters (Table 2). Paint A only contained TZn4, while the other paints (B-D) contained TZn4 and a "booster." These "boosters" were bismuth lactate (paint B), ZAg (paint $\mathrm{C}$ ), and $\mathrm{ZAgCl}$ (paint $\mathrm{D}$ ); their contents were $2 \%$, by weight, with respect to the total pigment concentration. Control paints were also elaborated with the same formula as paints A-D, but zinc "tannate" was replaced in volume by $\mathrm{TiO}_{2}$.

\section{Tests in sea water environment}

Paints were applied by brush on $8 \times 12 \mathrm{~cm}$ sandblasted acrylic panels to match a total dry film thickness of $200 \pm 5 \mu \mathrm{m}$; 24 hours passed between the application of each coat to allow the system to dry adequately. Not more than 48 h elapsed before immersion of the painted panels in NSW. Panels were attached to aluminum holders and immersed at a depth of $50-60 \mathrm{~cm}$ in Mar del Plata harbor $\left(38^{\circ} 08^{\prime} \mathrm{S}\right.$ 
Table 3: Settlement degree assessment

Settlement degree

Efficiency (\%)

0 , no settlement

100

1, little

80

2, limited

60

3, common

40

4, abundant

5 , completely covered

and $\left.57^{\circ} 31^{\prime} \mathrm{W}\right)$ during the high biological activity season. Biological and hydrological conditions of this harbor had been studied previously. ${ }^{35}$ Besides bacteria and diatoms, other species like barnacles, serpulidae, ascidians, bryozoans, algae, and polychaetes are the frequent fouling organisms encountered on hard substrates in Mar del Plata harbor. ${ }^{35}$

The panels were observed with the naked eye periodically and evaluated according to a six-degree scale (Table 3). ${ }^{9,36-38}$ The fouling settlement (FS) 0-1 implied no settlement or little settlement of soft foulers onto the panel. An increasing rating means an increased fouled area and a decreased efficiency of the antifouling paint. A rating higher than 1 implies that hard foulers like barnacles and serpulidae were attached onto the paints. Only panels qualified as 0 or 1 are considered satisfactory.

\section{Results and discussion}

\section{Pigment and "boosters" characterization}

The analysis of $\mathrm{TZn} 4$ showed that it contained $86.70 \%$ of tannin and $0.53 \%$ of zinc, the rest being water $(12.77 \%)$. The density of TZn4 was $1.43 \mathrm{~g} / \mathrm{mL}$. The concentration of TP in the saturated solution in ASW was $3.33 \mathrm{~g} / \mathrm{L}$, while that of zinc cation was $27 \mathrm{mg} / \mathrm{L}$. The metal content of the antifouling paints tested in this research was strikingly lower than that of commercial paints which may contain $20-40 \%$ of metals. ${ }^{39}$ The addition of boosters ( $2 \%$ ) did not increase metal content significantly.

The zeolitic rock employed in this investigation contained $15-30 \%$ of clinoptilolite, the rest being quartz (15-30\%), calcite (15-30\%), plagioclass (5-15\%), and clay $(5-15 \%)$. The amount of silver ion in exchanged $\mathrm{ZAg}$ was $25.1 \mathrm{meq} / 100 \mathrm{~g}$ of ground rock, while the modified ZAgCl contained $75.6 \mathrm{meq} / 100 \mathrm{~g}$.

\section{Bioassays}

After an incubation period of $24 \mathrm{~h}, \mathrm{LC}_{50}$ of zinc "tannate" was found to consist of $117 \pm 24 \mathrm{mg} / \mathrm{L}$ of TP and $0.97 \mathrm{mg} / \mathrm{L}$ of zinc cation.

$\mathrm{LC}_{50}$ of bismuth lactate was found to consist of $920 \pm 28 \mathrm{mg} / \mathrm{L}$ of lactate and $0.09 \pm 0.01 \mathrm{mg} / \mathrm{L}$ of

bismuth ion. None of the sodium lactate solutions was lethal to nauplii, and the results were similar to the control. The bioassay carried out with bismuth oxichloride solutions showed that the $\mathrm{LC}_{50}$ was achieved only with the saturated solution. This would indicate the greater biocidal efficiency of bismuth lactate than those of both lactate and bismuth ions.

When bismuth lactate dissolves, bismuth ion undergoes an intense hydrolysis:

$\mathrm{BiL}_{3} \Leftrightarrow \mathrm{Bi}^{3+}+3 \mathrm{~L}^{-}$

where $\mathrm{L}$ represents the lactate anion $\left(\mathrm{CH}_{3} \mathrm{CH}(\mathrm{OH})\right.$ $\left.\mathrm{COO}^{-}\right)$. The hydrolysis of $\mathrm{Bi}(\mathrm{III})$ occurs as follows ${ }^{39}$ :

$\mathrm{Bi}^{3+}+\mathrm{Cl}^{-}+\mathrm{H}_{2} \mathrm{O} \Leftrightarrow \mathrm{BiOCl}+2 \mathrm{H}^{+}, \quad K=4.79 \times 10^{6}$.

The solubility product constant is $K_{\mathrm{sp}}=\mathrm{K}^{-1}=2.09 \times$ $10^{-7}$.

The lactate anion also hydrolyzes as follows:

$$
\begin{aligned}
& \mathrm{L}^{-}+\mathrm{H}_{2} \mathrm{O} \Leftrightarrow \mathrm{HL}+\mathrm{OH}^{-}, \\
& K_{\mathrm{h}}=\frac{K_{\mathrm{w}}}{K_{\mathrm{a}}}=\frac{10^{-14}}{1.4 \times 10^{-4}}=7 \times 10^{-11}
\end{aligned}
$$

The equilibrium constant for the formation of the precipitate is much higher than the hydrolysis constant, $K_{\mathrm{h}}$, for lactate. Therefore, it was concluded that the formation of $\mathrm{BiOCl}$ is greatly favored with the concomitant diminution of the $\mathrm{pH}$ of the medium.

Other reactions usually could take place in sea water, but owing to the very high chloride concentration and the values of the equilibrium constants, those with chloride may be considered the most important ones. The precipitation of $\mathrm{BiOCl}$ would explain the low $\mathrm{pH}, 3.3$, registered in the saturated solution of the bismuth lactate in ASW. The solubility of bismuth may increase by chloride complexation ${ }^{40}$ :

$$
\begin{aligned}
& \mathrm{Bi}^{3+}+n \mathrm{Cl}^{-} \Leftrightarrow \mathrm{BiCl}_{n}{ }^{3-n}, \\
& \beta_{n}=\frac{\left[\mathrm{BiCl}_{6}{ }^{3-}\right]}{[\mathrm{Bi}(\mathrm{III})]\left[\mathrm{Cl}^{-}\right]^{6}}=2.5 \times 10^{7} \text { where } n=1-6
\end{aligned}
$$

The logarithms of the accumulative or gross constants $(\beta)$ are $\beta_{1}=10^{2}, \quad \beta_{2}=4.04, \quad \beta_{3}=5.3, \quad \beta_{4}=7.47$, $\beta_{5}=8.04$, and $\beta_{6}=7.36 .{ }^{40}$ The solubility $(S)$ of bismuth in a chloride medium depends on its value and on the chloride concentration.

$$
\begin{aligned}
& S=[\mathrm{Bi}(\mathrm{III})]+\left[\sum_{n=1}^{n=6} \mathrm{BiCl}_{n}{ }^{3-n}\right] \\
& S=[\mathrm{Bi}(\mathrm{III})]+\sum_{n=1}^{n=6} \beta_{n}[\mathrm{Bi}(\mathrm{III})]\left[\mathrm{Cl}^{-}\right]^{n} \\
& S=[\mathrm{Bi}(\mathrm{III})]+\left(1+\sum_{n=1}^{n=6} \beta_{n}\left[\mathrm{Cl}^{-}\right]^{n}\right)
\end{aligned}
$$




$$
S=\frac{K_{\mathrm{sp}}\left[\mathrm{H}^{+}\right]^{2}}{\left[\mathrm{Cl}^{-}\right]}\left(1+\sum_{n=1}^{n=6} \beta_{n}\left[\mathrm{Cl}^{-}\right]^{n}\right)
$$

The solubility of bismuth lactate in the saturated solution in ASW at $\mathrm{pH} 3.3$, calculated in this way, was $9.15 \times 10^{-7} \mathrm{M}(0.19 \mathrm{ppm})$ and may decrease as the $\mathrm{pH}$ increases. The experimental solubility was found to be $1.95 \mathrm{ppm}$.

The concentration of $\mathrm{Bi}(\mathrm{III})$ in the saturated solution of bismuth oxychloride in ASW may be calculated taking into account the adequate equilibrium:

$\mathrm{BiOCl}+\mathrm{H}_{2} \mathrm{O} \Leftrightarrow \mathrm{Bi}^{3+}+\mathrm{Cl}^{-}+2 \mathrm{OH}^{-}$

$\log K_{\mathrm{sp}}=-30.75$

$K_{\text {sp }}=\left[\mathrm{Bi}^{3+}\right]\left[\mathrm{Cl}^{-}\right]\left[\mathrm{OH}^{-}\right]^{2}$

The concentration of $\mathrm{Bi}(\mathrm{III})$ was found to be $7.98 \times 10^{-15} \mathrm{M}$, too low to be measured spectrophotometrically.

These results would indicate that there are two factors which determine bismuth lactate activity. On the one hand, the acidification of the medium, due to the hydrolysis of $\mathrm{Bi}(\mathrm{III})$, with direct consequences on the survival of marine organisms. On the other hand, $\mathrm{Bi}(\mathrm{III})$ biocidal activity was proven in the bioassay with bismuth oxychloride saturated solution which did not show any $\mathrm{pH}$ changes. The concentration of $\mathrm{Bi}(\mathrm{III})$ in the bismuth lactate solution increased sensibly with respect to the oxychloride and at the same time the $\mathrm{pH}$ is decreased, thus enhancing the biocidal action of bismuth lactate.

In spite of the reported action of silver on bacterial growth, ${ }^{14,16,18,41}$ bioassays with modified zeolites showed no lethal effect at any concentration. This fact may be attributed to the low equilibrium concentration of silver in ASW.

The ionic equilibrium of $\mathrm{ZAg}$ in ASW may be described according to the following equations:

$$
\begin{aligned}
& \mathrm{ZAg}+\mathrm{Na}^{+} \Leftrightarrow \mathrm{ZNa}+\mathrm{Ag}^{+} \\
& \mathrm{Ag}^{+}+\mathrm{Cl}^{-} \Leftrightarrow \mathrm{AgCl} \\
& \mathrm{AgCl} \Leftrightarrow \mathrm{Ag}^{+}+\mathrm{Cl}^{-}, \quad K_{\mathrm{sp}}=\left[\mathrm{Ag}^{+}\right]\left[\mathrm{Cl}^{-}\right]
\end{aligned}
$$

The solubility product constant $\left(K_{\mathrm{sp}}\right)$ of silver chloride was reported to be equal to $1.78 \times 10^{-10}$.

The solubility of silver chloride changes in sea water because of the presence of chloride governed by the following complexation reactions:

$$
\mathrm{Ag}^{+}+n \mathrm{Cl}^{-} \Leftrightarrow \mathrm{AgCl}_{n}^{(1-n)-}
$$

where $n=1-4$.

The accumulative equilibrium constants $(\beta)$ may be defined by the following equation:
$\beta_{n}=\frac{\left[\mathrm{AgCl}_{n}^{(1-n)-}\right]}{\left[\mathrm{Ag}^{+}\right]\left[\mathrm{Cl}^{-}\right]}$

The logarithms of these equilibrium constants are as follows ${ }^{40}$ :

$\beta_{1}=3.44, \beta_{2}=5.3, \beta_{3}=5.49, \beta_{4}=5.4$.

The solubility $(S)$ of silver chloride in sea water is commonly calculated according to the following equations:

$$
\begin{aligned}
S= & {\left[\mathrm{Ag}^{+}\right]+[\mathrm{AgCl}]+\left[\mathrm{AgCl}_{2}^{-}\right]+\left[\mathrm{AgCl}_{3}{ }^{2-}\right] } \\
& +\left[\mathrm{AgCl}_{4}^{3-}\right]=\left[\mathrm{Ag}^{+}\right]+K_{1}\left[\mathrm{Ag}^{+}\right]\left[\mathrm{Cl}^{-}\right] \\
& +\beta_{2}\left[\mathrm{Ag}^{+}\right]\left[\mathrm{Cl}^{-}\right]^{2}+\beta_{3}\left[\mathrm{Ag}^{+}\right]\left[\mathrm{Cl}^{-}\right]^{3}+\beta_{4}\left[\mathrm{Ag}^{+}\right]\left[\mathrm{Cl}^{-}\right]^{4} \\
S= & {\left[\mathrm{Ag}^{+}\right]\left(1+K_{1}\left[\mathrm{Cl}^{-}\right]+\beta_{2}\left[\mathrm{Cl}^{-}\right]^{2}+\beta_{3}\left[\mathrm{Cl}^{-}\right]^{3}+\beta\left[\mathrm{Cl}^{-}\right]^{4}\right) }
\end{aligned}
$$

where $\mathrm{Ag}^{+}=\frac{K_{\mathrm{sp}}}{\left[\mathrm{Cl}^{-}\right]}$.

According to the preceding equations, the solubility of silver chloride in the sea water is $4.51 \times 10^{-5} \mathrm{M}$ (6.4 ppm), considering that the concentration of chloride in ASW was $0.56 \mathrm{M}$. This value is a little higher than that in pure water $\left(1.33 \times 10^{-5} \mathrm{M}\right)$ because the chloride began to dissolve the silver chloride. Evidently, these low values of silver in solution are not enough to inhibit the growth of the bacterial film before macrofouling settlement. This is why the paints containing silver-modified zeolites failed after 2 months of exposure as will be seen in the next paragraph.

\section{Tests in sea water environment}

This assay was conducted in triplicate. Figures 1 and 2 show representative records obtained after 3,6 , and 9 months of exposure of the tested paints in NSW.

Figure 1 depicts the result obtained with the paint A. After 3 months, the FS was 5, thus indicating that the paint failed completely. Ascidians and bryozoans were attached to the panel in a greater proportion (Fig. 1). The paint film was in good condition, but the efficiency of the paint was unacceptable. The control paint $\mathrm{A}$, with $\mathrm{TiO}_{2}$ instead of $\mathrm{TZn} 4$, obtained a similar FS qualification (Fig. 2).

Paint B showed the best results: the FS was 1 after 6 months of immersion, and 1-2 after 9 months (Fig. 1). However, after 10 months, the paint failed completely; serpulidae, barnacles, bryozoans, and ascidians were found to be attached to the panels' surface. After three months of immersion, the panels coated with the zeolites containing paints (Paints C and D, Fig. 1) showed a much better performance than the control; however, 


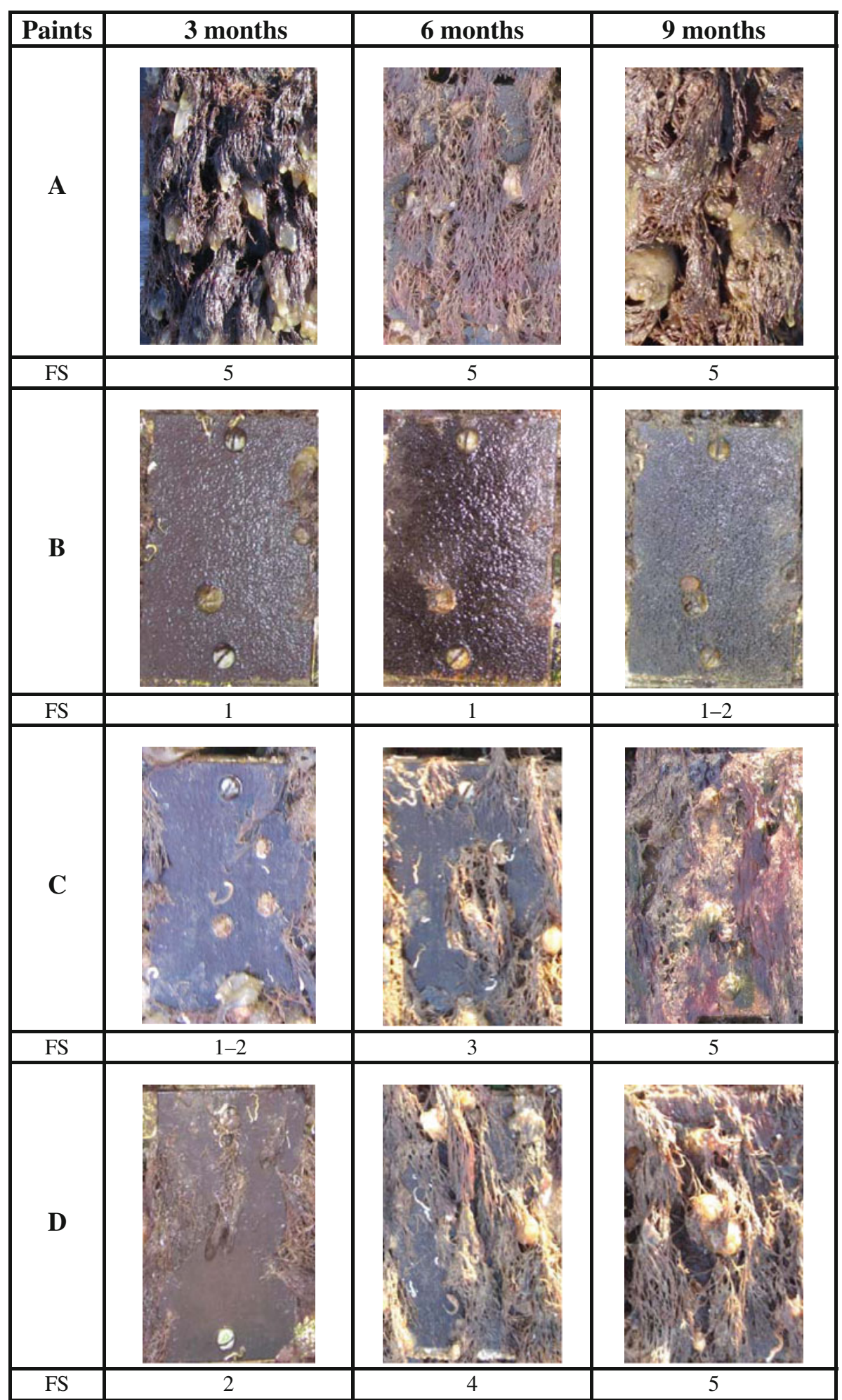

Fig. 1: Panels with experimental paints (A, B, C, and D) immersed in sea water environment and their fouling settlement (FS). All the formulations included TZn4 as the principal biocide

some slime, bryozoans, barnacles, and polychaetes were found to be attached to them. The FS ratings of these paints were 1-2 and 2 for paints $\mathrm{C}$ and $\mathrm{D}$, respectively.
The antifouling performance of the paint pigmented with zinc "tannate" did not differ significantly from the control paint containing titanium dioxide. However, paints' 


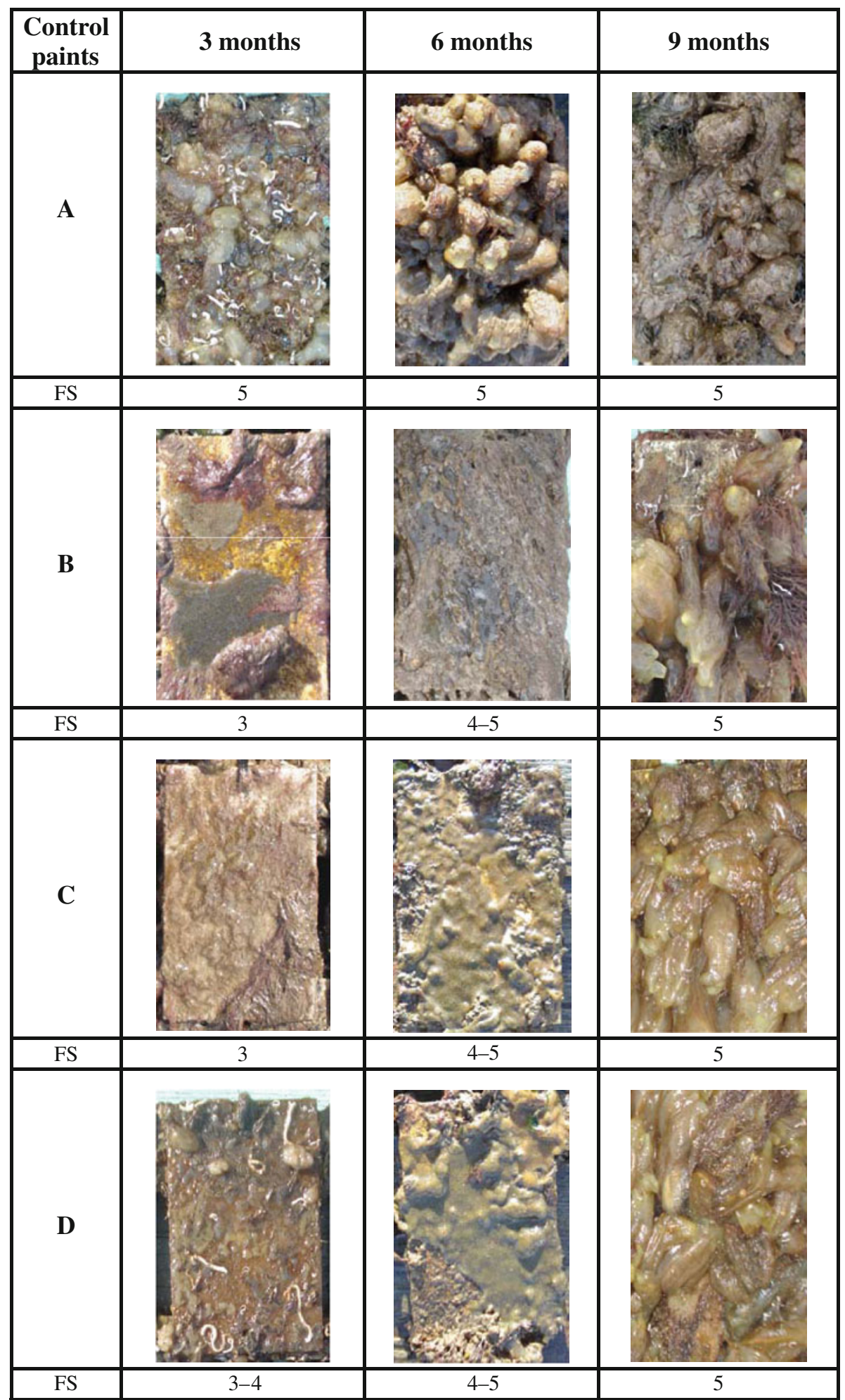

Fig. 2: Control panels of paints A, B, C and D immersed in sea water environment and their fouling settlement (FS). All formulations contained $\mathrm{TiO}_{2}$ in place of $\mathrm{TZn} 4$ biocide

antifouling performance improved when boosters were incorporated into the paint formulation. There seemed to be a synergism between the boosters and zinc "tannate" because the coating performance was better when both compounds were employed together. This finding was particularly noticeable in the case of bismuth lactate. 


\section{Conclusions}

- The study of ionic equilibrium in sea water could help to identify the bioactive species and explain the antifouling action of biocides.

- Low quantities of "booster" can modify the behavior of marine antifouling paint.

- The paints with the exchanged zeolite were more efficient than the blank, but the zeolite did not extend the paint's useful life significantly.

- Antifouling paint with zinc "tannate" and the "booster" bismuth lactate showed a higher efficiency up to 9 months of exposure to NSW.

- Bismuth lactate was proven to be active in the bioassays, bismuth being the more active species, but its most striking effect could be attributed to the decrease of the $\mathrm{pH}$ of ASW effected by bismuth ion hydrolysis.

Acknowledgments The authors wish to thank Consejo Nacional de Investigaciones Científicas y Técnicas (CONICET), Comisión de Investigaciones Científicas de la Provincia de Buenos Aires (CICBA), Agencia Nacional de Promoción Científica y Tecnológica (ANPCyT) and Universidad Nacional de La Plata (UNLP) for their support in carrying out this research.

\section{References}

1. Mukherjee, A, Mohan, KV, Ramesh, US, "Predicted Concentrations of Biocides from Antifouling Paints in Visakhapatnam Harbour." J. Environ. Manag., 90 S51-S59 (2009)

2. Le, Y, Hou, P, Wang, J, Chen, JF, "Controlled Release Active Antimicrobial Corrosion Coatings with $\mathrm{Ag} / \mathrm{SiO}_{2}$ Core-Shell Nanoparticles." Mater. Chem. Phys., 120 351-355 (2010)

3. Chambers, LD, Stokes, KR, Walsh, FC, Wood, RJK, "Modern Approaches to Marine Antifouling Coatings." Surf. Coat. Technol., 201 3642-3652 (2006)

4. Pérez, M, García, M, Blustein, G, Stupak, M, "Tannin and Tannate from the Quebracho Tree: An Eco-Friendly Alternative for Controlling Marine Biofouling." Biofouling, 23 (3/ 4) 151-159 (2007)

5. Laks, P, "Flavonoid Biocides: Phytoalexin Analogues from Condensed Tannins." Phytochemistry, 26 (6) 1617-1621 (1987)

6. Xie, D, Dixon, R, "Proanthocyanidin Biosynthesis-Still More Questions than Answers?" Phytochemistry, 66 21272144 (2005)

7. Scalbert, A, "Antimicrobial Properties of Tannins." Phytochemistry, 30 3875-3883 (1991)

8. Pérez, M, Blustein, G, García, M, del Amo, B, Stupak, M, "Cupric Tannate: A Low Copper Content Antifouling Pigment." Prog. Org. Coat., 55 311-315 (2006)

9. Bellotti, N, Deyá, C, del Amo, B, Romagnoli, R, "Antifouling Paint with Zinc "Tannate"." Ind. Eng. Chem. Res., 49 3386-3390 (2010)
10. Karlsson, J, Eklund, B, "New Biocide-Free Anti-Fouling Paints are Toxic." Mar. Pollut. Bull., 49 456-464 (2004)

11. Konstantinou, IK, Albanis, TA, "Worldwide Occurrence and Effects of Antifouling Paint Booster Biocides in the Aquatic Environment: A Review." Environ. Int., 30 235-248 (2004)

12. Konstantinou, I, Antifouling Paint Biocides. Springer, Berlin, 2006

13. Meyer, B, "Approaches to Prevention, Removal and Killing of Biofilms." Int. Biodet. Biodeg., 51 249-253 (2003)

14. Stobie, N, Duffy, B, Colreavy, J, McHale, P, Hinder, S, McCormack, D, "Dual-Action Hygienic Coatings: Benefits of Hydrophobicity and Silver Ion Release for Protection of Environmental and Clinical Surfaces." J. Colloid Interf. Sci., 345 286-292 (2010)

15. Arai, T, Harino, H, Ohji, M, Langston, WJ, Ecotoxicology of Antifouling Biocides. Springer, Tokyo, 2009

16. Redfield, A, Weiss, C, "The Resistance of Metallic Silver to Marine Fouling." Biol. Bull., 94 (1) 25-28 (1948)

17. Top, A, Ülkü, S, "Silver, Zinc, and Copper Exchange in a Na-Clinoptilolite and Resulting Effect on Antibacterial Activity." Appl. Clay Sci., 27 13-19 (2004)

18. Yang, HL, Lin, J, Huang, C, "Application of Nanosilver Surface Modification to RO Membrane and Spacer for Mitigating Biofouling in Seawater Desalination." Water Res., 43 3777-3786 (2009)

19. Fujino, J, Motontani, S, Inohara, K, Katsumura, R, Application Number: JP19870086523 19870407

20. GB 1000775, Applicant M\&T CHEMICALS INC, Application Number: GB19630046719 19631126

21. GB 1041058, Applicant M\&T CHEMICALS INC, Application Number: GB19630023641 19630613

22. Ferreira, E, Nogueira, A, Souza, G, Batista, L, "Effect of Drying Method and Length of Storage on Tannin and Total Phenol Concentrations in Pigeon Pea Seeds." Food Chem., 86 17-23 (2004)

23. Dominy, N, Davoust, E, Minekus, M, "Adaptive Function of Soil Consumption: An In Vitro Study Modeling the Human Stomach and Small Intestine." J. Exp. Biol., 207 319-324 (2004)

24. Erdemoğlu, SB, Gücer, Ş, "Selective Determination of Aluminum Bound with Tannin in Tea Infusion." Anal. Sci., 21 1005-1008 (2005)

25. Snell, FD, Snell, CT, Colorimetric Methods of Analysis. D. Van Nostrand Company, New York, 1941

26. Leyva, RR, Medellín, CN, Guerrero, CR, Berber, MM, Aragón, PA, Jacobo, AA, "Intercambio iónico de plata (I) en solución acuosa sobre clinoptilolita." Rev. Int. Contam. Ambient., 21 (4) 193-200 (2005)

27. Harris, DC, Análisis Químico Cuantitativo. Iberoam, México, 1992

28. Wilson, CL, Wilson, DW, Comprehensive Analytical Chemistry. Elsevier, London, 1960

29. Dahms, HU, Hellio, C, "Laboratory Bioassays for Screening Marine Antifouling Compounds." In: Hellio, C, Yebra, D (eds.) Advances in Marine Antifouling Coatings and Technologies, pp. 275-307. Woodhead Publishing Limited/CRC Press, Cambridge, 2009

30. Persoone, G, Jaspers, E, Clasus, C, "Ecotoxicological Testing for the Marine Environment." Proc. of the International Symposium on Ecotoxicological Testing for the Marine Environment Ghent, Belgium, 1983

31. Persoone, G, Wells, PG, "Artemia in Aquatic Toxicology: A Review." In: Sorgeloos, P, Bengtoson, DA, Decleir, W, Jaspers, F (eds.) Artemia Research and Its Applications. 
Morphology, Genetics, Strain Characterization, Toxicology, Vol. 1, pp. 259-275. University Press, Belgium, 1987

32. Vetere, V, Pérez, M, García, M, Deyá, M, Stupak, M, del Amo, B, "A Non-Toxic Antifouling Compound for Marine Paints." Surf. Coat. Int., 12 386-389 (1999)

33. Ortega-Morales, B, Chan-Bacab, M, Miranda-Tello, E, Fardeau, M, Carrero, J, Stein, T, "Antifouling Activity of Sessile Bacilli Derived from Marine Surfaces." Ind. Microbiol. Biotechnol., 35 9-15 (2008)

34. Díaz Baez, M, Bulus Rossini, G, Pica Granados, Y, "Métodos Estadísticos para el Análisis de Resultados de Toxicidad Ensayos toxicológicos y métodos de evaluación de calidad de aguas." In: Castillo, G (ed.) Estandarización, intercalibración, resultados y aplicaciones, Chap. 5. IDRC Books, Canada, 2004

35. Bastida, R, Martin, JP, La vida entre mareas: vegetales y animales de las costas de Mar del Plata. INIDEP, Mar del Plata, 2004
36. Del Amo, B, Giúdice, CA, Rascio, V, "Influence of Binder Dissolution Rate on the Bioactivity of Antifouling Paints." J. Coat. Technol., 56 63-69 (1984)

37. Del Amo, B, Giúdice, CA, Sindoni, O, "High Build Soluble Matrix Antifouling Paints Based on Vinyl Resin.” Prog. Org. Coat., 17 2287-2300 (1989)

38. Del Amo, B, Giúdice, CA, Villoria, G, "Antifouling Paints of High Sea Water Dissolution Rate." Eur. Coat. J., 1 8-14 (1990)

39. Ytreberg, E, Karlsson, J, Eklund, B, "Comparison of Toxicity and Release Rates of $\mathrm{Cu}$ and $\mathrm{Zn}$ from Anti-Fouling Paints Leached in Natural and Artificial Brackish Seawater." Sci. Total Environ., 408 2459-2466 (2010)

40. Sillén, L, Martell, A, Stability Constants of Metal-Ion Complexes. The Chemical Society, Burlington House, London, 1964

41. Kumar, R, Munstedt, H, "Silver Ion Release from Antimicrobial Polyamide/Silver Composites." Biomaterials, 26 2081-2088 (2005) 